\title{
Mapping Knowledge in the Economic Areas of Green Building Using Scientometric Analysis
}

\author{
Xue Xiao ${ }^{1,2, *}$, Martin Skitmore ${ }^{1,3}$, Heng $\mathrm{Li}^{2}$ and Bo Xia ${ }^{1}$ \\ 1 Science and Engineering Faculty, Queensland University of Technology, Brisbane 4000, Australia \\ 2 Department of Building and Real Estate, The Hong Kong Polytechnic University, Hong Kong \\ 3 Faculty of Computing, Engineering and the Built Environment, Birmingham City University, \\ Birmingham B4 7BD, UK \\ * Correspondence: xue.xiao@hdr.qut.edu.au
}

Received: 1 July 2019; Accepted: 1 August 2019; Published: 5 August 2019

check for updates

\begin{abstract}
This paper presents the first inclusive scientometric review of the economic areas of green building (GBE). The aim is to methodically examine and summarize the state-of-the-art of the GBE body of knowledge. To this end, this study analyses 1713 GBE-related bibliographic records retrieved from the Web of Science by using the quantitative method of knowledge mapping. The knowledge base, knowledge domain, and knowledge evolution of how they interacted with each other are explored using document co-citation analysis and keywords co-citation analysis of the existing body of literature. The research findings are informative in recognizing and interpreting the underlying structure and trends in GBE. A knowledge map provides a valuable and instructive understanding of the evolution and status quo of the GBE knowledge body, as well as assisting in recognizing the gaps and deficiencies involved. The results will help in understanding how GBE knowledge is evolving and its role played in green building, and thus provide suggestions of how academic research can enhance sustainability practices in terms of economic area in the future.
\end{abstract}

Keywords: economic area; green building; scientometric; review; knowledge map

\section{Introduction}

With the deteriorating environment and increasing pollution caused by urbanization, building sustainability has been the focus of much recent attention [1]. As one of the biggest energy consumers, building contributes approximately $40 \%$ to total energy consumption and one third of the annual amount of global greenhouse gas emissions [2]. Thus, green building has been introduced in an attempt to minimize the negative environmental influences of the construction and operation of buildings. Currently, researchers are actively pursuing answers to contribute to sustainable building development world-widely [3].

However, green building is not being adopted smoothly because of a variety of challenges and barriers [4]. Numerous studies have been conducted of the factors affecting the green building practice. Yang and Yang (2015), for example, explore the factors affecting the green building implementation in Australia, classifying them into four categories of technical and design, economic, sociocultural, and institutional factors [5]. Of these, economic factors are generally considered to have the greatest influence worldwide [5,6]. Research evidence has been found in both developed countries such as Australia [5] and developing countries including China [6] and Thailand [7]. Despite the considerable technology-related problems in green building practice, the most significant continue to be economic barriers [7], including such related factors such as market demand and lack of motivation from owners.

Nevertheless, little attention has been paid to the economic areas of green building (GBE) despite its great significance [3]. Several publications have concluded that greater effort is necessary to make 
the economic aspects mainstream features of green building [2,3]. As a practical research field, GBE is primarily associated with solving the practical economic issues involved in green building practice. It stems from green building movement and has a close connection with various green building practice. GBE addresses numerous aspects such as economic value, benefit, cost, price, investment, and finance. This broad coverage adds to the difficulties in understanding the GBE development, thus requiring to consider GBE publications and their association with other publications as a whole for providing a meaningful comprehension of GBE knowledge body.

Existing GBE reviews conducted by manual appraisals (e.g., [8-10]), are limited for providing a "trees" picture of a specific research topic and are unable to generate a systematic view of the proverbial "forest". For example, Russ et al.'s (2018) study was conducted by examining the cost premium involved [9], while Zhang et al. (2018) examine economic viability from different perspectives [10]; they both carefully examined their specific areas but were unable to provide a linkage with other topics. Besides, manual reviews are criticized for their lack of reproducibility, systemanticness, and subjective biases [11]. Moreover, due to constantly renewing GBE knowledge, it is significant to track the emerging trends and mark the milestones of the GBE knowledge body, while existing reviews of GBE fail to capture the turning points in research focus or provide any depth of understanding of the knowledge evolution.

Due to its great significance and the limitations of previous research, the present study presents an inclusive scientometric review of GBE. A quantitative and accurate method-knowledge mapping-is used to explore the literature for GBE's existing intellectual core and landscape (knowledge base, domain and evolution), and detect omissions and deficiencies as well as future directions. The findings in this study will help in understanding the underlying structure and evolution of GBE knowledge, and enhance future sustainability practices. The results will also assist practitioners in the green building industry by providing a valuable and updated reference of the economic-related issues in existing research.

\section{Background}

\subsection{Green Building}

Despite the increasing public awareness of green building, there is no consensus over what green building should cover or what green building is [3]. Therefore, it is necessary to understand some background of green building and the history of the green building movement, the start of which can be dated back to the rising awareness of environmentalism as well as the governmental response to the environmental movements in the form of policy initiatives [12]. Of several major milestones in the history of the green building movement, the formation of U.S. Green Building Council (USGBC) marks the formal participation of government in the provision of green building.

A wide variety of terminology is used in the long process of green building development, such as sustainable building, green construction, sustainable construction, sustainable housing, green housing, energy-saving building, and energy-saving housing $[8,13]$. Despite the interchangeability of these words, the term "green building" more frequently appears in the official name of organizations, institutions, and standards as exemplified by the World Green Building Council, Green Building Standard and Certification System, and Green Building Evaluation Standard. The underlying reason behind this might be the semantic difference between green and its synonyms. Compared with other terms, the label of green is more popular and simpler to be used and understood [14]. Green is typically associated with individual products and process, thus the concept of green building can be easily comprehended, exploited, and disseminated. Another semantic advantage of using green building is the scale and scope of the term "green" for eco-friendly aspects, as well as the resulting policies and practices [14]. Therefore, this manuscript uses green building as the predominant terminology. Other synonyms for green building from the previous literature are used additionally in the searching strategy to provide a comprehensive coverage of publications. 
Green building is most comprehensively concerned with the environmental, social and economic aspect of a building in the context of its community [13]. The definition of sustainability remains broad in the housing industry. Glavinich's (2008) definition of "a building that provides the specified building performance requirements while minimizing disturbance and improving the functioning of local, regional and global ecosystems both during and after its construction and specified service life" [15], for instance, emphasizes minimizing environmental impact. Yudelson on the other hand introduce a life cycle perspective in defining a green building as "a high-performance property which is designed to use less energy and water and to reduce the life-cycle environmental impacts of the materials used" [16].

Despite the various definitions, the major feature of green building is to improve human health and the environment, as well as resource efficiency. The sustainability of resource, environment, society, economy and health is the main characteristic of green building [5,17]. There is a consensus over a wide spectrum of green building advantages, the most predominant being energy saving [18]. Despite a few contrary opinions, in that there is no significant difference in energy consumption between green and their conventional counterparts $[19,20]$, the majority of studies find that green buildings do indeed consume less energy. More specifically, green building could reduce nearly $30 \%$ of energy usage on average [21,22]. Eco-housing projects in China with a particular green design, such as solar technology or prefabrication components, are reported as saving more than half the energy [23] and nearly one-fifth water consumption with LEED office buildings acknowledged to consume 18-39\% less energy per unit floor area than their non-green counterparts [24]. Additionally, several studies have identified such benefits as increased productivity, market value increment, and improved health, low maintenance costs, and competitiveness $[22,25,26]$.

Regardless of the various benefits involved, green building practice has encountered much resistance in its progress towards the mainstream market [27]. The most reported barriers to green building adoption in the literature are inadequate information, incremental cost, insufficient incentives, scant market motivation, and deficient policy and regulations [28]. However, these results differ according to the region involved. For example, the cost premium, the differences in the design of the existing buildings and green buildings, and insufficient economic incentives are the main barriers in Hong Kong [4]; government- and company-related barriers are the most important in Ghana [29]; -sustainability strategies and company policies play a more significant role in Norway, the UK; and the U.S. [30]; while social and cognitive barriers account for the major green building practice challenges in Vietnam [27]. Despite regional differences, economic related issues are listed as the most influential in green building practice almost everywhere [31]. Numerous studies has emphasized the significance of GBE and concluded that greater attention are necessary for promoting GBE development [2,3].

\subsection{Green Building Economics}

As a practical field of study, GBE stems from green building practice and generally lacks a clear outline of the research field. The development of GBE can be dated back with the pioneering efforts in energy conservation for buildings in the U.S. in 1970s. The booming of green building movement made detailed knowledge in various aspects become important [32]. GBE, due to the significance of economic areas in green building practice, starts to receive research attention. GBE is primarily associated with solving the practical economic issues of green building; for example, the key issue of the economic assessment of energy consumption, or the core question of whether or not green building costs more than its conventional counterpart [8]. With the rapid and large-scale increase in green building practice, research effort is not limited to individuals, but are also extended to the study of promoting green building development as an industry.

GBE is closely linked with building economics or construction economics and it is necessary to know its scope and to ascertain why it is distinct from building economics. Building economics, or construction economics, can be defined as the study of the ways in which the resources available to the construction industry may be appropriately allocated and optimally used [33]. It consists of the 
application of the techniques and economics to the study of the building firm, the construction process, and the whole industry [34]. Rakhra and Wilson (1982) divide the application of economics to building into two parts: building project economics and building industry economics [35]. Economics research at the project level aims to ensure the funds invested in building are most appropriately spent, while economics studies at the industry level seek to overcome, or at least alleviate, the difficulties faced by the building industry. However, researchers and practitioners seldom make such a distinction because the two parts are tightly interrelated.

The research domain of building economics is concerned with identifying the optimal allocation of resources for building owners and developers. However, optimal allocation for a single stakeholder or a single stage does not necessarily result in overall optimal investments, nor does such a local optimum have any direct benefit on the optimal allocation for a society. To achieve the overall development of environment and society, green building is designed to use less energy and water and to reduce the life-cycle environmental impacts of the materials involved [16]. Thus, the economics based study of green building is concerned with identifying the optimal allocation of resources to have a minimum disturbance and improve the functioning of ecosystems both during and after construction and specified service life.

Referring to Rakhra and Wilson's (1982) concept, the scope of GBE in this study comprises two levels: the green building project level and green building industry level [35]. GBE at the project level mainly considers economic assessment and the corresponding problems of green building from the life-cycle perspective. It demonstrates the feasibility of various green building designs and such renewable energy technologies as solar [36], wind [37], green roofs [38] and green material [39]. Meanwhile, GBE at the industry level focuses on studying the barriers involved and seeking the solution for green building development from an industry economic perspective. It provides various insight into green building industry promotion $[23,31]$ and the long-term influence of green building on the economic growth of society $[40,41]$. These two parts are interacted with each other and inextricably linked. Therefore, the scope of GBE in this study includes the collateral costs and benefits of using sustainable practices from both the project and industry level. Understanding this GBE scope is significant because it provides an instructive guide for searching the literature.

\section{Research Method}

This study uses scientometric analysis as the primary method to explore the research field. Compared with bibliometric analysis, scientometric analysis provide a broader view, where an insightful structure and dynamic trends can be obtained [2]; when combining with visualization tools, it provides valuable and concrete insights into the research domain, especially the underlying evolutionary subjects involved [42].

The research is conducted in consecutive stages of tools selection, data collection, data processing and analysis, visualization and presentation, interpretation and discussion of findings [43]. The process of knowledge mapping here includes two stages referring to former research [44]. The first involved constructing networks through document co-citation analysis, keywords co-occurrence analysis, cluster identification analysis, and citation burst analysis, followed by the second stage of generating maps for representing and interpreting useful information.

\subsection{Science Mapping Tool Selection}

As GBE is an emerging multi-disciplinary research field that includes construction, economics, and the environment, it is required that software tools should not only be able to reveal the major research questions involved, but also their dynamic evolution over time. CiteSpace is used here to exploit the GBE's knowledge base, knowledge domain, emerging trends, and their evolution due to its advantage of categorizing data into different time sub periods to exploit the evolution of a longitudinal study [44-46]. 
Citespace provides several different types of network construction from bibliographic data, including document co-citation, keyword co-citation, and author co-citation. Following previous studies [2,44], document co-citation analysis, keyword co-citation analysis, cluster identification, and burst detection is used for knowledge mapping. Firstly, document co-citation analysis is used to represent the overall GBE bibliographic network and high impact publications, to provide a very quick understanding of mainstream GBE research. Secondly, keyword co-occurrence analysis is used to detect the knowledge base responsible for the fertile development of GBE. Thirdly, cluster identification is conducted to reveal the core GBE research domain. In this process, closely related publications are classified into the same cluster given the hypothesis that if two documents are frequently jointly cited, it is more likely they share similar scientific knowledge or concepts. Thus, the core GBE research domain becomes evident. Finally, the citation burst of publications and keywords are examined to illustrate the evolution of GBE. Together they provide a powerful knowledge map for displaying the intellectual landscape and knowledge evolution of the GBE research field.

\subsection{Data Collection}

Bibliographic records were collected from the Web of Science (WoSTM) Core Collection following a previous study [44]. The WoS is the most historical citation database and provides a cross-disciplinary citation search. It covers a variety of citation databases, including the Conference Proceedings Citation Index, Science Citation Index, Social Sciences Citation Index, Arts \& Humanities Citation Index, and Book Citation Index. Compared with such other data source as Scopus and Google scholar, WoS has the advantage of strong coverage from as early as 1990 and involving mostly high impact journals [47,48].

Given the scope of GBE, the searching strategy comprises two steps: firstly, "green building" and its synonyms is used for searching publications related to green building by referring to earlier review studies $[2,8-10,49]$. Secondly, "economic", "benefit", and "cost" are identified as the primary keywords for narrowing the topic related to economic area. Other economic-related keywords from previously green studies are also used [49-54]. Therefore, topics related to the terms "energy-saving building" or "green building" or " sustainable building" or "energy- efficient building" or " energy-saving construction" "green construction" or " sustainable construction" or "energy-efficient construction" or "energy-saving hous" or "green hous" or "sustainable hous*" or "energy-efficient hous*" and topics related to the term "economic" or "cost" or "benefit" or "value" or "price" or "incentive" or "investment" or "payment" or "capital" or "financial" were used to retrieve the bibliographic data. The wildcard character* is used to capture variations of a word, such as house and housing. Although this study intends to provide a good coverage of the topic, it does not include all potential terms because of the arduous and costly nature of doing so [55,56]. Other words including renewable energy, embodied energy and green design are feasible for improving this research field in the future. Document type is limited to "article". The reason for this is that journal articles generally contains the most high quality research, and their knowledge considered as "certified knowledge" in science mapping [57]. The timespan is set to all years. As of 22 May 2019, 1713 publications were obtained and exported in the form of full records (including author and author affiliations, source journal, title, keywords, and abstract) and cited references in plain-text format, forming the dataset in this study.

\section{Analysis and Results}

\subsection{Document Co-Citation Analysis}

Figure 1 illustrates the result of the document co-citation network with the 509 nodes and 1396 links generated by CiteSpace. The time slice is set to one year and top-cited publication during each slice is restricted to the top 50 publications. The node represents the cited reference and the link represents how closely two publications are related by using the frequency they are cited together by other publications. The color of the areas differs according to the first appearance of the co-citation 
links-the warmer the color, the later the co-citation. Additionally, a larger node size suggests that the publication is cited more frequently and implies its greater importance in the GBE research area.

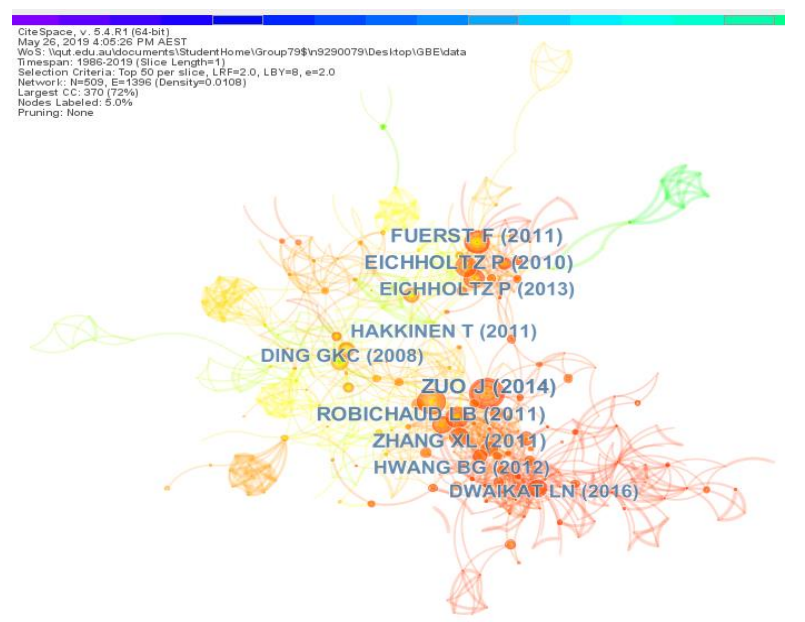

Figure 1. Document co-citation network of GBE.

It can be seen from Figure 1 that GBE is an emerging research field with many red and yellow in nodes and links. The whole network presents a much-decentralised structure, which illustrates GBE's multi-disciplinary characteristics. The 10 most cited publications from 1986 to 2019 are shown in Table 1; browsing these provides a very quick understanding of mainstream GBE related research and its major trends.

Several influential publications are review-oriented. The most influential publications carefully examine the existing body of research knowledge related to green building. Several concepts and benefits involved in green building are well examined in the literature, including the environmental, economic, and human aspects [3]. Robichaud and Anantatmula provide an overview of research related to green project management [58]. Later, the controversial research question of whether green building costs more or less than its conventional counterpart is explored by examining 17 empirical studies of the green building cost premium [8]. Another overview examines regional differences in existing environmental building assessment methods in terms of their characteristics and limitations [59]. Despite the difference in the topics, these publications provide an influential overview of the specific area related to GBE and introduce the general background of GBE development.

The analysis of the drivers and barriers to the adoption of green building is another mainstream topic in the 10 most cited references [60-62], representing the research focus at the GBE industry level. A total of three studies explore the drivers and barriers of the sustainable development in different countries (Finland, Singapore, and China). Their results again illustrate incremental cost to be the top-ranked barrier, and economic incentives from the government or the market remains a significant driver.

Table 1. Top ten critical GBE publications.

\begin{tabular}{|c|c|c|c|c|c|}
\hline No. & Author & Title & Source & Year & $\begin{array}{c}\text { Cited } \\
\text { Frequency }\end{array}$ \\
\hline 1 & $\begin{array}{l}\text { J. Zuo; } \\
\text { Z. Y. Zhao }\end{array}$ & $\begin{array}{c}\text { Green building research-current } \\
\text { status and future agenda: } \\
\text { A review }\end{array}$ & $\begin{array}{l}\text { Renewable and } \\
\text { Sustainable } \\
\text { Energy Reviews }\end{array}$ & 2014 & 48 \\
\hline 2 & $\begin{array}{l}\text { L. B. Robichaud; V. S. } \\
\text { Anantatmula }\end{array}$ & $\begin{array}{l}\text { Greening project management } \\
\text { practices for } \\
\text { sustainable construction }\end{array}$ & $\begin{array}{l}\text { Journal of Management } \\
\text { in Engineering }\end{array}$ & 2011 & 41 \\
\hline
\end{tabular}


Table 1. Cont.

\begin{tabular}{|c|c|c|c|c|c|}
\hline No. & Author & Title & Source & Year & $\begin{array}{c}\text { Cited } \\
\text { Frequency }\end{array}$ \\
\hline 3 & $\begin{array}{c}\text { F. Fuerst; } \\
\text { P. McAllister }\end{array}$ & $\begin{array}{c}\text { Green noise or green value? } \\
\text { measuring the effects of } \\
\text { environmental certification on } \\
\text { office values }\end{array}$ & Real Estate Economics & 2011 & 39 \\
\hline 4 & $\begin{array}{c}\text { X. L. Zhang; A } \\
\text { Platten; LY Shen }\end{array}$ & $\begin{array}{c}\text { Green property development } \\
\text { practice in China: costs } \\
\text { and barriers }\end{array}$ & $\begin{array}{l}\text { Building and } \\
\text { Environment }\end{array}$ & 2011 & 34 \\
\hline 5 & $\begin{array}{l}\text { P. Eichholtz; } \\
\text { N. Kok; } \\
\text { J. M. Quigley }\end{array}$ & $\begin{array}{l}\text { Doing well by doing good? } \\
\text { green office buildings }\end{array}$ & $\begin{array}{c}\text { American } \\
\text { Economic Review }\end{array}$ & 2010 & 34 \\
\hline 6 & $\begin{array}{l}\text { P. Eichholtz; } \\
\text { N. Kok; } \\
\text { J. M. Quigley }\end{array}$ & The economics of green building & $\begin{array}{l}\text { Review of Economics } \\
\text { and Statistics }\end{array}$ & 2013 & 29 \\
\hline 7 & $\begin{array}{l}\text { B. G. Hwang; } \\
\text { J. S. Tan }\end{array}$ & $\begin{array}{c}\text { Green building project } \\
\text { management: obstacles and } \\
\text { solutions for } \\
\text { sustainable development }\end{array}$ & $\begin{array}{l}\text { Sustainable } \\
\text { Development }\end{array}$ & 2012 & 29 \\
\hline 8 & $\begin{array}{l}\text { T. Häkkinen; } \\
\text { K. Belloni }\end{array}$ & $\begin{array}{l}\text { Barriers and drivers for } \\
\text { sustainable building }\end{array}$ & $\begin{array}{l}\text { Building Research \& } \\
\text { Information }\end{array}$ & 2011 & 28 \\
\hline 9 & $\begin{array}{l}\text { L. N. Dwaikat; } \\
\text { K. N. Ali }\end{array}$ & $\begin{array}{l}\text { Green buildings cost premium: } \\
\text { A review of empirical evidence }\end{array}$ & Energy and Buildings & 2016 & 28 \\
\hline 10 & G. K. C. Ding & $\begin{array}{l}\text { Sustainable construction-The } \\
\text { role of environmental } \\
\text { assessment tools }\end{array}$ & $\begin{array}{c}\text { Journal of } \\
\text { Environmental } \\
\text { Management }\end{array}$ & 2008 & 28 \\
\hline
\end{tabular}

The remainder of the studies focus on the financial performance of green building in the marketplace. Eco-certified office buildings are considered to have a higher financial return in the rental and selling price $[63,64]$ and rental rate [63]. Additionally, the finance returns to green buildings have not been affected by the volatility in property markets [25]. These publications conclude that increased energy efficiency is fully capitalised into rents and asset values.

\subsection{Keyword Co-Occurrence Analysis}

Keyword co-occurrence analysis provides an effective way to demonstrate the knowledge base of a research domain. It provides the basic knowledge and deeper insights into the development of the particular research field because keywords offer a concise and precise high-level summarization of an article [65]. Table 2 lists the 60 most used terms, with a total of 2219 co-occurrence frequencies, which accounts for more than $75 \%$ of all keyword frequencies. "Green building" and its synonyms used for searching publications are excluded as they comprise a large proportion and provide general background information [66], and therefore there is no additional value in analyzing these words. Moreover, not all the keywords provided by the authors are normalised; thus, the extracted keywords are standardized to ensure the consistent treatment of unifying synonyms. For example, "Life cycle assessment", "LCA", and "Life cycle assessment" (LCA) are identified as "Life cycle assessment"; "Building information modelling", "Building information modelling", and "BIM" are identified as "BIM". 
Table 2. Most frequently used keywords.

\begin{tabular}{cccccc}
\hline Count & Keywords & Count & Keywords & Count & Keywords \\
\hline 129 & Performance & 37 & Environment & 19 & Driver \\
125 & Life cycle assessment & 31 & Consumption & 19 & Energy saving \\
113 & Design & 30 & BIM & 18 & Emission \\
111 & Energy & 29 & Economics & 18 & Methodology \\
108 & Energy efficiency & 28 & Life cycle cost & 17 & Fly ash \\
86 & System & 27 & Efficiency & 17 & Climate change \\
78 & Model & 24 & Innovation & 16 & Strategy \\
71 & Management & 24 & Genetic algorithm & 15 & Waste \\
69 & Optimization & 24 & Market & 14 & Construction project \\
64 & LEED & 23 & Behavior & 13 & Thermal performance \\
62 & Impact & 23 & Environmental impact & 13 & Risk \\
60 & Barrier & 22 & Renewable energy & 13 & Energy conservation \\
57 & Sustainable development & 22 & Mechanical property & 13 & Technology \\
57 & Cost & 21 & Industry & 13 & Strength \\
46 & Construction industry & 21 & Framework & 12 & Quality \\
45 & Residential building & 21 & Hong Kong & 11 & Developing country \\
44 & Policy & 21 & Energy consumption & 11 & Incentive \\
44 & Concrete & 20 & Health & 11 & Selection \\
42 & Simulation & 19 & Office building & 11 & Indicator \\
38 & China & 19 & Challenge & 10 & Geopolymer \\
\hline
\end{tabular}

Figure 2 shows the keyword co-occurrence network labelled with the $75 \%$ most frequently occurring keywords. In total, there are 244 nodes and 1065 links in the overall network. A node in the network represents one keyword and a line between two nodes represents a co-occurrence link. The size of a node illustrates the frequency with which a keyword occurs. The different colors of lines are designed to show when a connection is made for the first time.

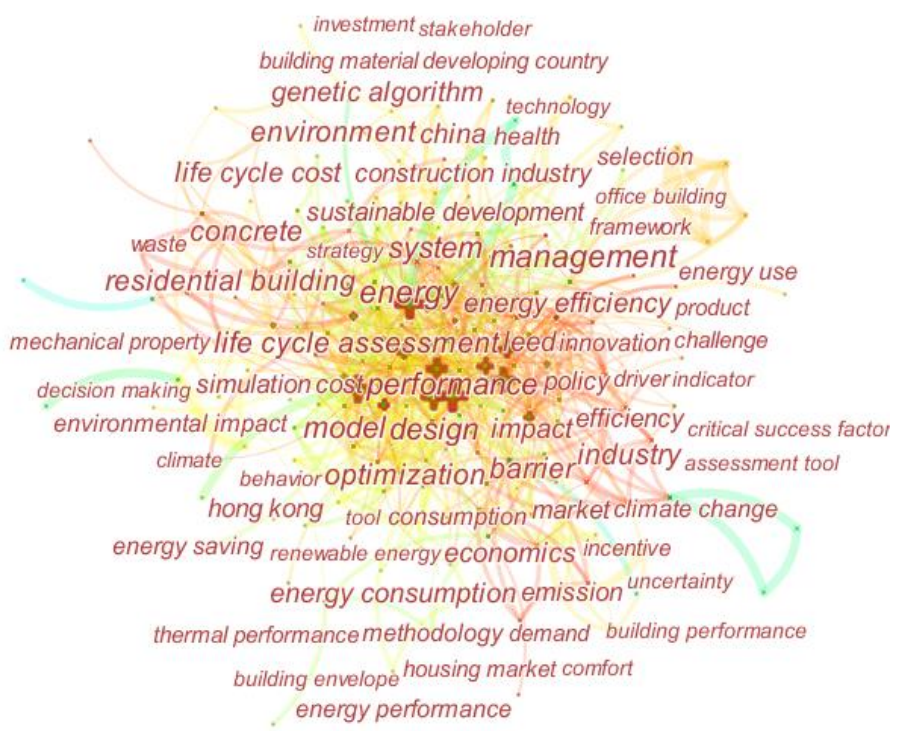

Figure 2. Keyword co-occurrence network.

As can been seen from Figure 2 and Table2, various keywords are extracted in this study. Despite the scattered information represented by these words, several groups can be detected. The most frequently used terms are energy/energy efficiency/performance/renewable energy/energy consumption/energy conservation, which indicates the essential attributes of green building and the initial knowledge base of GBE.The amount of work in the research domain of the energy performance of green building inevitably results in research attention on its economic assessment. Thus, the second significant 
keyword group contains terms including life cycle assessment/life cycle cost. Life cycle assessment (LCA) is a methodology for evaluating the environmental load of processes and products during their life cycle from cradle to grave [67]. Numerous studies exploit this to examine the benefits involved, such as energy saving and carbon emission reductions [68,69] and health [70]. The life cycle is a significant concept in LCA. The initial and after-stage is included in LCA as well as the construction stage. This special research attention in the design stage is because any revisions after the design stage is considered uneconomic [71]. The initial decision has a considerable impact on the depletion of building performance resources and waste emissions during the whole life cycle [72].

Another group detected in the keywords includes the various factors influencing green building implementation. Such terms as barrier, driver, challenge, strategy, strength, risk, impact, policy, cost, and management to some extent represent the role GBE plays in green building development. The state-of-the-art of sustainable building has attracted much attention all over the world [58,60-62] and various influencing factors have been explored $[5,6,73]$. Of all the factors involved, the high initial cost of green building is considered to have the most negative influence on green building implementation worldwide $[5,6,27]$. Thus, the green building cost premium started to receive attention from researchers. The cost premium consists of several sustainable elements, including materials, equipment, technology, design, tendering, the contractor's experience, and insurance [9]. Despite being naturally assumed that expenditure on sustainable elements results in an inevitably higher cost of green building, there is insufficient empirical evidence concerning the question of whether or not green building costs more than its conventional counterpart [8].

Meanwhile, positive influencing factors have also gained research attention. Terms including economics and the market represent a group of studies that mainly focus on market demand and financial returns, including the rental and sale price premium $[25,64,65,74]$. Studies of the financial performance of green building in the marketplace, including the rental and sale price premium, are significant because market demand is a strong motivation for promoting green building practices.

Technological advance is another fundamental driver for sustainable building development [7]. Such terms as mechanical property, BIM, thermal performance, fly ash, technology, concrete, waste, and geopolymer represent the technical group of green building studies. Green building requires high-level green technical capabilities [7] and various green technology such as thermal storage [75], geopolymer [76] and waste reduction [77] have been proposed. Meanwhile, the advanced technique approaches such as energy simulation [78,79], optimization modelling [80,81], and hybrid systems $[82,83]$ have been introduced for innovative modelling in green building practice and characterized by such keywords terms as system, model, optimization, and simulation.

\subsection{Cluster Identification and Interpretation}

After exploring the knowledge base of GBE through the keyword co-citation analysis, the second step is to investigate clusters of publications to identify the core knowledge area of GBE and their hidden links. Cluster analysis provides a clear map of the intellectual base of the underlying specialty. The noun terms are extracted from the title, keywords, or abstract and the most frequently encountered noun phrase becomes the label of that cluster. Three statistical methods including the log-likelihood ratio (LLR) test [84], term frequency-inverse document frequency (TF*IDF) [85] and mutual information (MI) tests are applied in this process.

This study mainly introduces the top 10 clusters because the remaining clusters are relatively small. Figure 3 illustrates these, labelled with abstract terms by using MI algorithm. The network has a high modularity of 0.7915 , which suggests that the network has been adequately categorised into loosely coupled clusters [86]. The silhouette measures the homogeneity of each group and can be seen in Table 3. Each cluster has a silhouette greater than 0.8 , indicating that the object is well matched to its own cluster and poorly matched to neighboring clusters. Thus the results are efficient and reliable [87]. The average silhouette score of 0.3462 is mainly due to the influence of small clusters. 
The total amount of publications in the cluster determines the size of a cluster. The cluster with the largest size is numbered as \#0, with the smallest size being \#9.

Given the differences in the labels produced by LSI, LLR, and MI, the top three terms produced from each method are presented to help obtain a better interpretation of context, as shown in Table 3 . Given the advantage of extracting useful information from massive data, the label produced by the MI test is used in Figure 3 to avoid meaningless repetition. It is very interesting to find that the body of GBE knowledge has core specialties that include green consumerism, rework factors, cost premium, infrastructure planning, sustainable building (SB) rating systems, commercial retrofits, value stream mapping, life cycle assessment (LCA), building life-cycle cost, and minimizing upgrade costs.

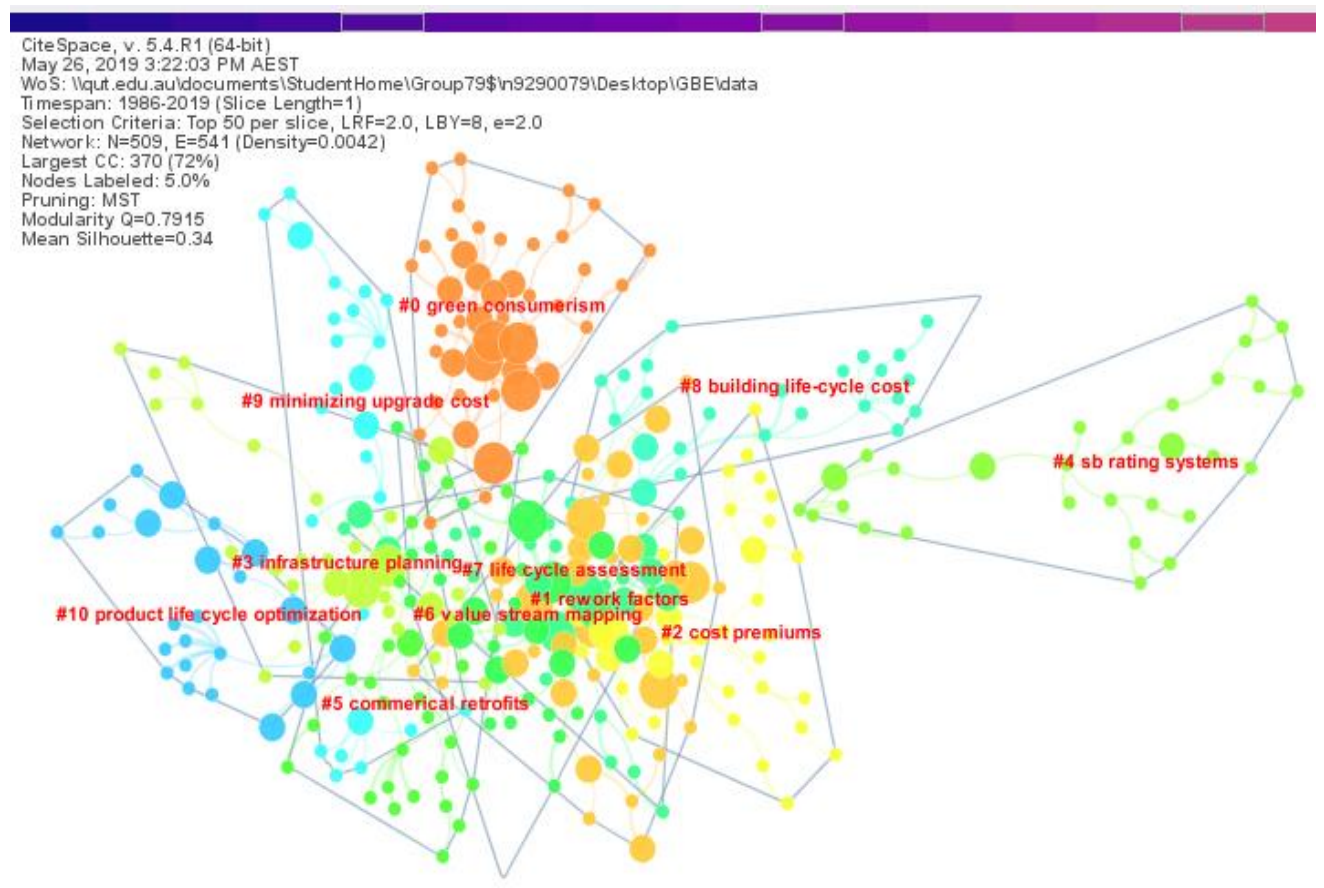

Figure 3. Clusters of knowledge domains.

The top three GBE clusters are large (above 30), which indicates that more publications are relevant to these research areas. The most significant cluster is green consumerism, which comprises 44 studies. From the keywords including green consumerism, features, indoor environmental quality, decision-making, tenant, energy performance, and residential building property, the common issue related to this cluster can be detected. The topics of these studies include the various benefits of green building, elements involved to encourage green consumerism behaviour, the tenant's willingness to pay for GB, and the factors influencing green decision-making. The second largest cluster is the rework factor. The studies in this cluster focus on the adoption of green building technologies (GBTs), and such GB technology rating assessment as rework. The third significant cluster is the cost premium. Studies in this cluster are related to topics that include the comparison of cost between conventional and green building, the influence of incremental cost, and the strategy for promoting the adoption of green building. Given the labels that include GBT adoption and promotion strategies produced by LSI and LLR, the cost premium is identified as the dominant barrier for GBT adoption, which is widely confirmed in the literature $[23,60,61]$. 
Table 3. Top ranked cluster and labels produced by LSI, LLR, and MI.

\begin{tabular}{|c|c|c|c|c|c|c|}
\hline$I^{1}$ & $\mathrm{Si}^{2}$ & $\mathrm{~S}^{3}$ & $\mathbf{M}^{4}$ & Label (MI) & Label (LSI) & Label (LLR) \\
\hline 0 & 44 & 0.89 & 2010 & $\begin{array}{c}\text { Green consumerism; } \\
\text { Decision-making; } \\
\text { Tenant }\end{array}$ & $\begin{array}{l}\text { Features; Indoor } \\
\text { environmental } \\
\text { quality; Criteria }\end{array}$ & $\begin{array}{l}\text { Indoor environmental } \\
\text { quality; Energy } \\
\text { performance; Residential } \\
\text { building property }\end{array}$ \\
\hline 1 & 38 & 0.82 & 2012 & $\begin{array}{c}\text { Rework factors; } \\
\text { Rating tools; Green } \\
\text { building construction } \\
\text { projects }\end{array}$ & $\begin{array}{c}\text { Adoption; GBTs; } \\
\text { Construction industry }\end{array}$ & $\begin{array}{l}\text { Purchasing intention; } \\
\text { Green housing; } \\
\text { Green building }\end{array}$ \\
\hline 2 & 34 & 0.87 & 2014 & $\begin{array}{l}\text { Cost premiums; } \\
\text { Delivery methods; } \\
\text { Collaboration }\end{array}$ & $\begin{array}{l}\text { GBTs adoption; GBTs; } \\
\text { Promotion strategies }\end{array}$ & $\begin{array}{c}\text { GBTs adoption; } \\
\text { Promotion strategies; } \\
\text { GB development research }\end{array}$ \\
\hline 3 & 29 & 0.87 & 2008 & $\begin{array}{l}\text { Infrastructure planning; } \\
\text { Planning and scheduling; } \\
\text { Building materials }\end{array}$ & $\begin{array}{c}\text { Knowledge; } \\
\text { Developers; Actions }\end{array}$ & $\begin{array}{c}\text { Flooring system; } \\
\text { Sustainable building; } \\
\text { Construction process }\end{array}$ \\
\hline 4 & 29 & 0.94 & 2014 & $\begin{array}{c}\text { SB rating systems; } \\
\text { Environmental aspects; } \\
\text { Assessment }\end{array}$ & $\begin{array}{l}\text { Energy simulation; } \\
\text { Interoperability; } \\
\text { Order }\end{array}$ & $\begin{array}{l}\text { Building information; } \\
\text { Sustainable urban-poor } \\
\text { housing; SB attribute }\end{array}$ \\
\hline 5 & 28 & 0.90 & 2008 & $\begin{array}{l}\text { Commercial retrofits; } \\
\text { Artificial neural network; } \\
\text { Multiple regression }\end{array}$ & $\begin{array}{l}\text { Green projects; } \\
\text { Preproject planning } \\
\text { efforts; Cost } \\
\text { performance }\end{array}$ & $\begin{array}{l}\text { Green project; } \\
\text { Preproject planning effort; } \\
\text { Cost performance }\end{array}$ \\
\hline 6 & 28 & 0.80 & 2011 & $\begin{array}{l}\text { Value stream mapping; } \\
\text { Policy and regulations; } \\
\text { construction firms practices }\end{array}$ & $\begin{array}{l}\text { GBTs adoption; GBTs; } \\
\text { Ghana }\end{array}$ & $\begin{array}{c}\text { Schedule performance; } \\
\text { Green building project; } \\
\text { Delivering green building } \\
\text { project }\end{array}$ \\
\hline 7 & 27 & 0.91 & 2011 & $\begin{array}{c}\text { Life cycle assessment; } \\
\text { Sustainable target value; } \\
\text { Transaction cost }\end{array}$ & $\begin{array}{l}\text { Adoption; Barriers; } \\
\text { Respondents }\end{array}$ & $\begin{array}{c}\text { GB technologies; } \\
\text { Promoting GBTs adoption; } \\
\text { Target value design }\end{array}$ \\
\hline 8 & 25 & 0.95 & 2015 & $\begin{array}{l}\text { Building life-cycle cost; } \\
\text { Sustainable assessment; } \\
\text { Green building rating tools }\end{array}$ & $\begin{array}{l}\text { Green buildings; } \\
\text { Adoption; Method }\end{array}$ & $\begin{array}{c}\text { Assessment model; } \\
\text { Construction industries; } \\
\text { Sub- criteria }\end{array}$ \\
\hline 9 & 25 & 0.94 & 2009 & $\begin{array}{l}\text { Minimizing upgrade cost; } \\
\text { Life cycle cost; } \\
\text { Sustainability of existing } \\
\text { buildings }\end{array}$ & $\begin{array}{l}\text { Design element; } \\
\text { Building designer; } \\
\text { Existing building }\end{array}$ & $\begin{array}{c}\text { Version; } \\
\text { Building designers; } \\
\text { Credits }\end{array}$ \\
\hline
\end{tabular}

The remaining clusters differ little in cluster size. The fourth cluster is infrastructure planning. Together with the other key terms, including planning and scheduling, knowledge, and developers, studies in this cluster mainly focus on the planning of green building. Planning is significant because it provides the fundamental value and criteria for the whole stage of green building [88]. Likewise, studies in the fifth cluster are closely related to topics that include green building rating systems and their standards, assessment of the environment and energy performance, and BIM's participation in green building. Another noticeable cluster is life cycle assessment (LCA). LCA is a well-known analytical tool for assessing the environmental impacts of a product from a cradle-to-grave perspective. This approach enables the management and assessment of the incremental cost caused by green design and their energy consumption benefits.

Other clusters, including value stream mapping and commercial retrofits, also play an important role in GBE. Value stream mapping (VSM) is a widely used methodology in lean production as an intermediate step leading to process improvements [89]. Likewise, commercial retrofitting is a practical 
approach for turning a conventional building green, and studies of this topic and minimising the upgrade cost also contribute to green building development.

\subsection{Citation Burst Detection}

The citation-based indicators are limited because of the reliance on citations accumulated over time and the likelihood of overlooking newly published articles. An alternative method is to focus on the extent to which a newly published article contributes to the conceptual structure of the knowledge domain of interest [90]. Thus 'burst detection' is exploited in this study. Citation burst provides evidence that the publication has attracted an extraordinary degree of attention from its scientific community [91].

Figure 4 represents the 25 keywords with strongest citation bursts and Figure 5 represents the 20 strongest. The article or keyword with the high citation burst often denotes a disciplinary research focus or turning point. These bursts clearly mark the milestone of a research domain. Thus observing the start time and duration of the bursts reveals the evolution of the research domain and helps detect hotspots and emerging trends [92]. Of all the bursts detected, sustainable development has the strongest citation strength of 7.6448, building materials and the community (2002-2011) have the longest burst duration, while drivers and risk (2017-2019) are the latest popular topics.

\section{Top 25 Keywords with the Strongest Citation Bursts}

\begin{tabular}{lllll}
\multicolumn{1}{c}{ Keywords } & \multicolumn{1}{c}{ Year } & Strength Begin & End \\
building material & 1986 & 3.0953 & $\mathbf{2 0 0 2}$ & 2011 \\
community & 1986 & 6.0251 & $\mathbf{2 0 0 2}$ & 2011 \\
energy efficiency & 1986 & 3.1046 & $\mathbf{2 0 0 3}$ & 2008 \\
sustainable development & 1986 & 7.6448 & $\mathbf{2 0 0 6}$ & 2013 \\
green building design & 1986 & 3.2205 & $\mathbf{2 0 0 8}$ & 2014 \\
environment & 1986 & 4.079 & $\mathbf{2 0 0 9}$ & 2012 \\
trend & 1986 & 3.7456 & $\mathbf{2 0 1 0}$ & 2011 \\
embodied energy & 1986 & 3.6853 & $\mathbf{2 0 1 0}$ & 2013 \\
thermal insulation & 1986 & 3.7456 & $\mathbf{2 0 1 0}$ & 2011 \\
uncertainty & 1986 & 3.0932 & $\mathbf{2 0 1 0}$ & 2011 \\
sustainable design & 1986 & 3.0464 & $\mathbf{2 0 1 1}$ & 2015 \\
investment & 1986 & 3.186 & $\mathbf{2 0 1 1}$ & 2013 \\
cost control & 1986 & 3.6398 & $\mathbf{2 0 1 1}$ & 2012 \\
comfort & 1986 & 2.814 & $\mathbf{2 0 1 2}$ & 2013 \\
climate & 1986 & 3.7838 & $\mathbf{2 0 1 2}$ & 2015 \\
information & 1986 & 3.1315 & $\mathbf{2 0 1 3}$ & 2015 \\
envelope & 1986 & 4.1381 & $\mathbf{2 0 1 3}$ & 2014 \\
perception & 1986 & 4.1381 & $\mathbf{2 0 1 3}$ & 2014 \\
environmental impact & 1986 & 5.6401 & $\mathbf{2 0 1 3}$ & 2015 \\
home & 1986 & 3.6993 & $\mathbf{2 0 1 4}$ & 2015 \\
quality & 1986 & 3.3808 & $\mathbf{2 0 1 4}$ & 2015 \\
uk & 1986 & 3.6993 & $\mathbf{2 0 1 4}$ & 2015 \\
building envelope & 1986 & 3.1824 & $\mathbf{2 0 1 5}$ & 2016 \\
driver & 1986 & 5.5239 & $\mathbf{2 0 1 7}$ & 2019 \\
risk & 1986 & 3.0689 & $\mathbf{2 0 1 7}$ & 2019 \\
& & &
\end{tabular}

Figure 4. Top 25 keywords with strongest citation burst. 
Top 20 References with the Strongest Citation Bursts

$\left.\begin{array}{lllll}\multicolumn{1}{c}{\text { References }} & \text { Year } & \text { Strength } & \text { Begin } & \text { End } \\ \text { KATS G, 2003, COSTS FINANCIAL BENE, V0, P0 } & 2003 & 6.5798 & \mathbf{2 0 0 5} & 2010\end{array}\right]$

Figure 5. Top 20 reference with the strongest citation bursts.

Figures 4 and 5 together reveal the three periods in GBE development. The first period, before 2002, is relatively uneventful, without any keywords and high-profile references in terms of citation bursts. The second stage is from 2002 to 2009, with noticeable terms that include sustainable development, building material, community, energy efficiency, green building design, and environment. This period features the fundamental theoretical concepts and knowledge of green building. The high-impact references published in this period are characterized by introducing the fundamental theoretical concepts. Kats' (2003) study of green building economic benefit is influential, and Kibert (2008) later introduced fundamental knowledge of green building design and delivery. Energy performance, as the main attribute of green building, has been generally studied and evaluated. The influential studies of energy performance in this period include a literature survey of building energy performance [18] and its payoff $[24,93]$. The research domain of assessment methodology also gained attention $[59,67,94,95]$ and special effort has been made concerning green building at the design stage [72,81,96].

The third period is from 2010. Unlike the first two periods, this is full of high-impact contributions. Numerous citation bursts of keywords that appeared in this period include trend, embodied energy, thermal insulation, uncertainty, investment, cost control, comfort, climate, information, envelope, perception, environmental impact, home, quality, building envelope, drivers, and risk. Despite the difference in these terms, this period is characterized with the more practical assessment and more diversified evaluation of green building. Researchers started to pay more attention to issues related to the economic assessment of specific green building practice and the role GBE plays in the green building industry. The publications started to show their influence, and a new burst of references occurred. The various benefits of green building were identified [70] and the detailed influencing elements of green building practice examined, including strategy [23], obstacles [61], supply [50], challenges [97], and critical factors. Meanwhile, investment and cost control also started to attract research attention. High-impact studies of green building market demand and its financial return further support the necessity for developing green building [63]. Additionally, studies started to extend economic assessment for the retrofitting of existing building or in expenditure to obtain higher energy performance in the construction phase of new buildings [71]. This period features the diversified practical economic assessment of specific green building practices and the market affordability of green building. 


\section{Discussion}

\subsection{GBE Knowledge Map}

As a practical research field, GBE is an emerging research field based on loads of basic study on green building practice. Therefore, the knowledge map of GBE is formed in a bottom-up manner as shown in Figure 5 [98]. The GBE knowledge map consists of three major components of the knowledge base, knowledge domain, and knowledge evolution. As the foundation of the GBE knowledge map, the knowledge base provides the knowledge that fertile publication in the GBE and promote knowledge generation. It consists of the top 60 terms representing the $75 \%$ most frequently occurring keywords. Energy performance, as the impetus for green building development, happens to be the most frequently appearing group of keywords in GBE. This result marks the essential attributes of green building and indicates the close association between GBE and the practical issues in green building practice. The research work in green building energy areas also contributes to the great attention paid to life cycle assessment, a significant approach for green building decision making [99]. Additionally, technical terms related to how to achieve green building are also very popular. Terms including mechanical property, BIM, thermal performance, fly ash, technology, concrete, and waste, construct a solid foundation for the economic assessment of specific green building technology or design, as well as the research attention paid to the advanced approaches to energy simulation or cost optimization, characterized by such terms as system, model, optimization, and simulation. The large proportion of these technical terms illustrates the significant role of technology adoption in green building development, as well as its facilitation of GBE. Meanwhile, the increasing trend toward green building has shifted research attention to the development of green building as a whole industry. The various influencing factors on green building practice at the industry level are labelled by such terms as barrier, driver, challenge, strategy, strength, risk, impact, policy, cost, and management. The positive and negative influencing factors are examined in various regions [4,29-31,60-62]. The results of the keywords co-occurrence analysis provide a clear view of the knowledge base that fertilizes GBE and its role in GBE development.

Knowledge domain consists of the core GBE themes including green consumerism, rework factors, cost premiums, infrastructure planning, sustainable building (SB) rating systems, commercial retrofits, value stream mapping, life cycle assessment (LCA), sustainable target value (STV), and minimizing upgrade costs. In the process of knowledge evolution of GBE, some studies might have more emphasis on different aspect of economic issues. These core research domains can be organized into two pillars: the theory pillar and the practice pillar. The theory pillar contains the studies that introduced the foundational concepts and systematic approaches to GBE, including green consumerism, sustainable target value, and life cycle assessment, while the practice pillar addresses the specific practical issues of green building practice, including rework factors, cost premiums, infrastructure planning, sustainable building (SB) rating systems, commercial retrofits, building life-cycle cost, and minimizing upgrade costs. Analysis these clusters provides us a significant clue to understand the core knowledge in existing GBE, as well as assisting to find the deficiencies and limitations. Finally, the citation bursts are detected to identify the popular periodic issues. The beginning and the end of the citation burst reveals how the popular GBE research topics change over time. From 2002 to 2009, the noticeable keywords include building material, sustainable development, community, energy efficiency, green building design, and the environment. This period features the fundamental theory of green building and is closely linked with the construction of the knowledge base. The second stage is from 2010, which is characterised by the more practical assessment of green building technology and more diversified evaluation of green building types. Special attention is also paid to issues related to the role played by GBE in the green building industry, as drivers and risks have the latest burst citation. The main knowledge domain of GBE is formed in this stage.

The knowledge base, knowledge domain, and knowledge burst together clearly reveal the evolution of GBE. As shown in Figure 6, the top layer is labelled with the basic research aims to 
provide a building that is affordable, accessible and environmentally conscious [100]. It is only when each influencing aspect of green building is fully understood, that they can wholly contribute to promoting green building practice. The research findings in this study are instructive in identifying and understanding the GBE pattern and trends, and how these are linked. It should be noted that the GBE knowledge body might change in the future because of the rapid expansion of this field. However, the method and proposed framework in present study will be useful for accommodating future changes.

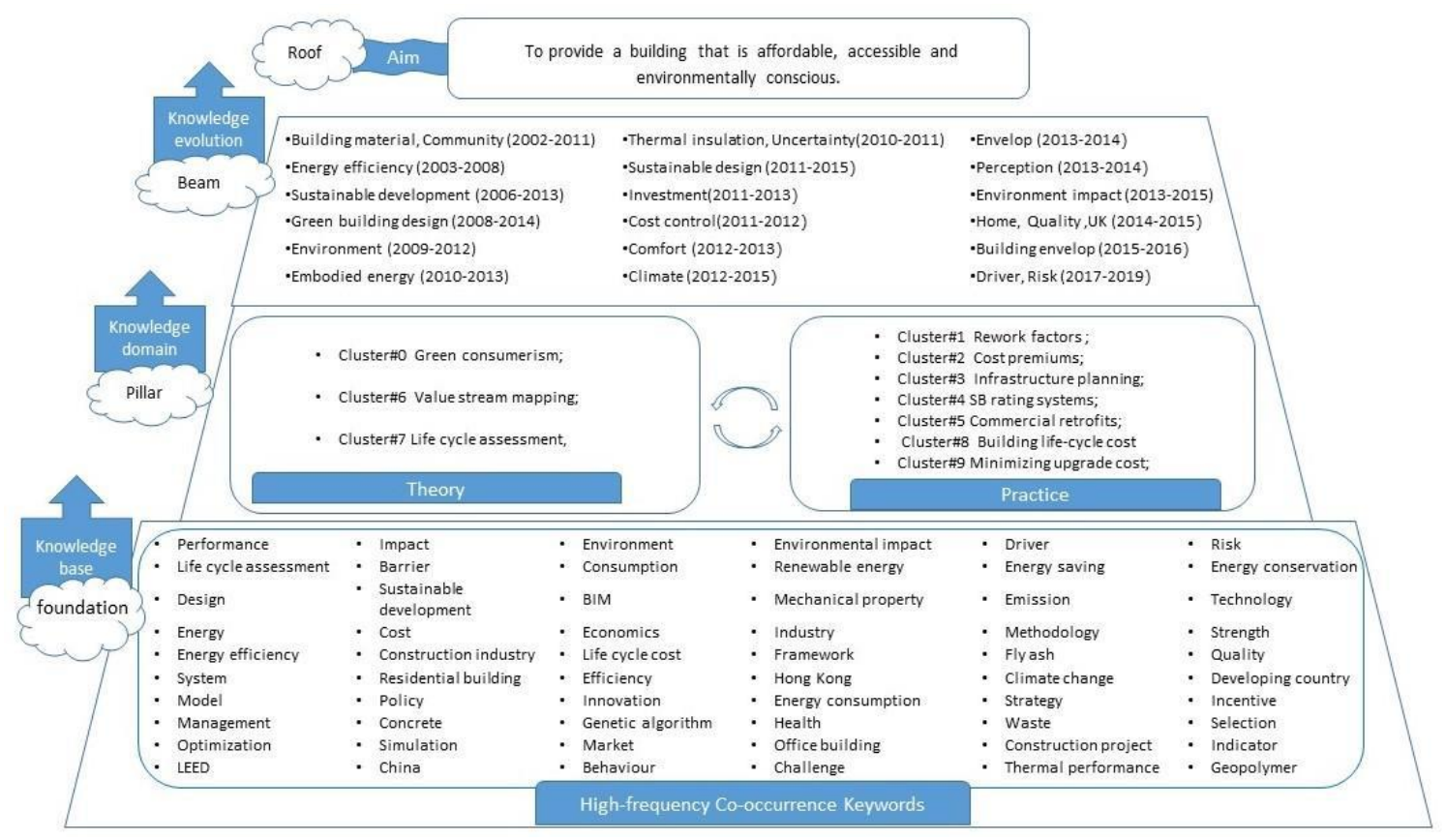

Figure 6. GBE knowledge map.

\subsection{Limitations and Recommendations}

This comprehensive and systematic analysis of the large corpus of GBE literature has revealed gaps and limitations. Since GBE is closely associated with solving the practical economic issues of green building, an important limitation of existing GBE publications is their scale and capacity compared with rapidly emerging green building practice. The quantity and the quality of GBE publication does not reflect the significance of the problem. Several review studies have concluded that GBE is largely overlooked in the existing green building research [2,3]. According to the results of the cluster identification, green consumerism, green building rework and retrofitting, cost premium, green building planning, green building rating system, value stream mapping, life cycle assessment and minimizing green building upgrade cost have become the main focus of GBE. However, there is a lack of diversity in the main research domains and the existing GBE studies have attracted special attention to particular topics while seriously neglecting other topics.

The theory pillar of GBE should be improved in the breadth and depth of the research theories and methods. Green consumption, as the largest cluster of GBE, provides the social background of GBE development. It is a term referring a wide range of eco-friendly activities and coming to mean all things to all people [101]. The scope of green consumption becomes abroad when it comes to building industry. It should be not limited to the energy consumption of green building, but should also include the various green behaviors involved in building practice. Despite its significant influence on GBE development, there is a lack of variety in research attention on stakeholder's behaviors and their conflicts. As well, the research effort on studying barriers and drivers for motivating stakeholders directly and indirectly is far from enough. The remainder in the theory pillar includes value stream mapping and life cycle assessment. As the important decision making tools for green building practice, 
these approaches require the good quality of input data. Thus, they are criticized for their limited flexibility of information and time arrangement $[102,103]$. Therefore, it is necessary to pay greater attention on simplifying and upgrading the existing approaches in GBE, as well as introducing and developing new theoretical approaches.

The practical pillar of GBE should establish the linkage with various emerging green building practice. As green building has triple bottom line referring to the three dimensions of social, environmental and economic aspect [104]. The research limitation of each aspect is not independent from deficiency in other aspect due to their mutual influence. Of all the green building aspects involved, the economic issues relating to the environmental aspect have received the most attention, while other aspects are mostly neglected [2]. As publications on social aspect of green building are largely missing, the connection between social aspect and economic aspect has not been soundly established and explored. The studies on economic issue relating to social aspect is less than adequate. Despite several studies on living comfort, occupational health and productivity $[70,105]$, there is a lack of diversity in research effort on mining and quantifying the benefit of social aspects of green building. This deficiency fails to provide guidance to fully fulfilling green building's potential, as well as raising the level of averageness of the society in the further. Moreover, GBE should go beyond empirical research to embrace the innovative concepts and theory for providing economic guidance for green building development. Finally, studies from the industry level are largely incomplete and more work needs to be devoted to the green building market and policy.

To address the limitations in existing GBE, the following suggestions in terms of green building cost, benefits, technology, management, and market and policy need to be implemented:

- Greater effort in providing empirical evidence on the controversial issue of whether the initial or life cycle cost of green building is higher than its conventional counterpart should be made. More work needs to be done on understanding the green building cost and its components because of their large influence on the initial decision making of a building in terms of technology and design [106]. Additionally, further study on the influence of advanced green building designs and technologies on cost, and the strategies to optimize sustainability under the limited green building budget should be encouraged.

- GBE publications should play a bigger role in illustrating how much benefit green building produces and how to achieve green building. The direct benefits of green building, including energy efficiency, water efficiency, and waste production appear to be central to research efforts [49]. However, focusing solely on the evaluation of direct benefits is insufficient for fully fulfilling green building's potential. Existing studies of the indirect benefits of green building including comfort level, employee productivity, health, retention, and recruiting are less than adequate. Consequently, more studies are necessary to address and quantify the indirect benefits [70], as well as improving the willingness to pay for green building.

- Given the significance of green technologies, more work is needed to fully understand the cost and the benefit of existing technologies in green building practice. The economic issues related to the key factors for technology adoption should be further explored. Additionally, greater research effort should be made on strategies of applying green technologies under different budget limitations and conditions.

- Further research is required in resolving conflicts of interest in green building management. The building contractors' perspective is clearly different from that of the owners. The benefits of introducing an energy efficient design into a building, for example, are incommensurate with the increase in property value [71]. Economic theories such as game theory and agent cost need to be better cooperated with GBE studies, as well as strategies for dealing with conflicts of interest between stakeholders [107].

- Because effective policies could align incentives to enhance the demand for green building, more research effort should be made on the green building industry level. Green building policies are designed to address market efficiency and this requires the fully understanding of the cost 
premium and incremental benefits involved. Therefore, future research is encourage to analyzing the existing green building policies and corresponding market conditions in different regions to provide the empirical evidence for effective policymaking. Greater attention should also be paid to analyzing the resale or rental asset value of green building, as well as examining green building market volatility.

\section{Conclusions}

GBE is a multi-disciplinary research field concerned with ecological, social, and economic influences. This paper presents the outcomes of an inclusive science mapping analysis of the body of literature concerning GBE from its advent in 1986 to the present (2019). It provides a clear picture of the structure of the GBE knowledge body by referring to 1713 GBE-related literature. Specifically, the overall GBE bibliographic network and high impact publications are explored using document co-citation analysis to provide a quick understanding of the GBE mainstream. The most frequently used 60 terms, with a total of 2219 co-occurrence frequencies (accounting for more than $75 \%$ of all keywords), are identified as the GBE knowledge base. In addition, the top ten knowledge clusters are identified, comprising green consumerism, rework factors, cost premium, infrastructure planning, sustainable building (SB) rating systems, commercial retrofits, value stream mapping, life cycle assessment (LCA), building life-cycle cost, and minimizing upgrade costs. The theory and practice pillars are proposed from the cluster label. The theory pillar is characterized by the GBE theoretical framework of green consumerism, sustainable target value, and life cycle assessment, while the practice pillar addresses the practical issues of green building rework factors, cost premiums, infrastructure planning, sustainable building (SB) rating systems, commercial retrofits, building life-cycle cost, and minimizing upgrade costs. Moreover, together with the knowledge base, knowledge domain, and burst detection, the evolution of GBE knowledge is revealed. From 2002 and 2010, several bursts including building materials, community, energy efficiency, sustainable development, green building design, environment, embodied energy, thermal insulation, and uncertainty are considered as the indicators of the formation of the knowledge base. From 2011 to the present, the citation bursts of sustainable design, investment, cost control, comfort, climate, perception, environment impact, home, quality, UK, building envelop, driver, and risk mark the research indirection and evolution of GBE.

The main uniqueness of this research is to use knowledge mapping for systematically analysing, representing and interpreting the GBE knowledge body, including the knowledge base, knowledge domains, and knowledge evolution. The research findings will help in understanding the underlying knowledge structure and evolution of GBE, and thus providing practical directions of how to address the drawbacks in the existing literature and offer promising further directions. It also assists in the integration of academia and industry by providing a valuable and updated reference of the economic issues related to green building practice in existing research. Moreover, compared with the traditional manual literature reviews, the method used in this article can be generalised and used as an effective tool for mapping knowledge in other disciplines.

Despite its major contributions, this study has several limitations. This study uses certain keywords to retrieve GBE publications and does not include all potential terms. Thus the research findings might not fully reflect the entire available literature relating to GBE. Additionally, keywords might be dependable based on changing culture and values, therefore may result in the difference in the connotation of some concepts. Also, this research used the dataset extracted from the WOS and therefore the quality of data used may be influenced by any limitations of WOS's coverage in publications. The limitations of the present study should be considered when interpreting the results. Future periodical studies are recommended to constantly address the limitations involved by the use of data from a variety of sources, searching strategies and indicators.

Author Contributions: X.X. contributes to the conception and design of the study, analysis and interpretation of data, drafting of the article. M.S. contributes to the supervision and revision of the article for important intellectual content and language. H.L. and B.X. contribute to the supervision and revision of the article. 
Funding: This research received no external funding.

Conflicts of Interest: The authors declare no conflict of interest.

\section{References}

1. Jiang, S.; Wang, N.; Wu, J. Combining BIM and ontology to facilitate intelligent green building evaluation. J. Comput. Civ. Eng. 2018, 32, 04018039. [CrossRef]

2. Darko, A.; Chan, A.P.C.; Huo, X.; Owusu-Manu, D.-G. A scientometric analysis and visualization of global green building research. Build. Environ. 2019, 149, 501-511. [CrossRef]

3. Zuo, J.; Zhao, Z.-Y. Green building research-current status and future agenda: A review. Renew. Sustain. Energy Rev. 2014, 30, 271-281. [CrossRef]

4. Wadu Mesthrige, J.; Kwong, H.Y. Criteria and barriers for the application of green building features in Hong Kong. Smart Sustain. Built Environ. 2018, 7, 251-276. [CrossRef]

5. Yang, J.; Yang, Z. Critical factors affecting the implementation of sustainable housing in Australia. J. Hous. Built Environ. 2015, 30, 275-292. [CrossRef]

6. Shi, Q.; Zuo, J.; Huang, R.; Huang, J.; Pullen, S. Identifying the critical factors for green construction-An empirical study in China. Habitat Int. 2013, 40,1-8. [CrossRef]

7. Shen, W.; Tang, W.; Siripanan, A.; Lei, Z.; Duffield, C.; Hui, F. Understanding the green technical capabilities and barriers to green buildings in developing countries: A case study of Thailand. Sustainability 2018, 10, 3585. [CrossRef]

8. Dwaikat, L.N.; Ali, K.N. Green buildings cost premium: A review of empirical evidence. Energy Build. 2016, 110, 396-403. [CrossRef]

9. Russ, N.M.; Hanid, M.; Kho, M.Y. Literature review on green cost premium of sustainable building construction. Int. J. Technol. 2018, 9, 1715-1725. [CrossRef]

10. Zhang, L.; Wu, J.; Liu, H. Turning green into gold: A review on the economics of green buildings. J. Clean. Prod. 2018, 172, 2234-2245. [CrossRef]

11. Hammersley, M. On 'Systematic' reviews of research literatures: A 'narrative' response to Evans \& Benefield. Br. Educ. Res. J. 2001, 27, 543-554. [CrossRef]

12. Korkmaz, S.; Erten, D.; Syal, M.; Potbhare, V. A review of green building movement timelines in developed and developing countries to build an international adoption framework. In Proceedings of the Fifth International Conference on Construction in the 21st Century: Collaboration and Integration in Engineering, Management and Technology, Istanbul, Turkey, 20-22 May 2009.

13. Xiao, X.; Skitmore, M.; Hu, X. Case-based reasoning and text mining for green building decision making. Energy Procedia 2017, 111, 417-425. [CrossRef]

14. Ernest, J.; Yanarella Richard, S.; Levine Robert, W.; Lancaster. Research and Solutions: "Green" vs. Sustainability: From Semantics to Enlightenment. Sustain. J. Rec. 2009, 2, 296-302. [CrossRef]

15. Glavinich, T.E. Contractor's Guide to Green Building Construction: Management, Project Delivery, Documentation, and Risk Reduction; John Wiley \& Sons: Hoboken, NJ, USA, 2008. [CrossRef]

16. Yudelson, J. The Green Building Revolution; Island Press: Washington, DC, USA, 2010; ISBN 978-1-59726-178-4.

17. Cole, R.J. Building environmental assessment methods: Redefining intentions and roles. Build. Res. Inf. 2005, 33, 455-467. [CrossRef]

18. Sartori, I.; Hestnes, A.G. Energy use in the life cycle of conventional and low-energy buildings: A review article. Energy Build. 2007, 39, 249-257. [CrossRef]

19. Hu, M. Does zero energy building cost more?-An empirical comparison of the construction costs for zero energy education building in United States. Sustain. Cities Soc. 2019, 45, 324-334. [CrossRef]

20. Scofield, J.H. Do LEED-certified buildings save energy? Not really ... . Energy Build. 2009, 41, 1386-1390. [CrossRef]

21. Kats, G. Green Building Costs and Financial Benefits; Massachusetts Technology Collaborative: Boston, MA, USA, 2003. Available online: http://www.greenspacebuildings.com/wp-content/uploads/2011/05/Kats-GreenBuildings-Cost.pdf (accessed on 3 August 2019).

22. Ries, R.; Bilec, M.M.; Gokhan, N.M.; Needy, K.L. The economic benefits of green buildings: A comprehensive case study. Eng. Econ. 2006, 51, 259-295. [CrossRef] 
23. Zhang, X.; Shen, L.; Wu, Y. Green strategy for gaining competitive advantage in housing development: A China study. J. Clean. Prod. 2011, 19, 157-167. [CrossRef]

24. Newsham, G.R.; Mancini, S.; Birt, B.J. Do LEED-certified buildings save energy? Yes, but ... . Energy Build. 2009, 41, 897-905. [CrossRef]

25. Eichholtz, P.; Kok, N.; Quigley, J.M. The economics of green building. Rev. Econ. Stat. 2013, 95, 50-63. [CrossRef]

26. Lau, L.C.; Tan, K.T.; Lee, K.T.; Mohamed, A.R. A comparative study on the energy policies in Japan and Malaysia in fulfilling their nations' obligations towards the Kyoto Protocol. Energy Policy 2009, 37, 4771-4778. [CrossRef]

27. Nguyen, H.-T.; Skitmore, M.; Gray, M.; Zhang, X.; Olanipekun, A.O. Will green building development take off? An exploratory study of barriers to green building in Vietnam. Resour. Conserv. Recycl. 2017, 127, 8-20. [CrossRef]

28. Darko, A.; Chan, A.P. Review of barriers to green building adoption. Sustain. Dev. 2017, 25, 167-179. [CrossRef]

29. Darko, A.; Chan, A.P.C.; Yang, Y.; Shan, M.; He, B.-J.; Gou, Z. Influences of barriers, drivers, and promotion strategies on green building technologies adoption in developing countries: The Ghanaian case. J. Clean. Prod. 2018, 200, 687-703. [CrossRef]

30. Collins, D.; Junghans, A.; Haugen, T. Green leasing in commercial real estate: The drivers and barriers for owners and tenants of sustainable office buildings. J. Corp. Real Estate 2018, 20, 244-259. [CrossRef]

31. Chan, A.P.C.; Darko, A.; Olanipekun, A.O.; Ameyaw, E.E. Critical barriers to green building technologies adoption in developing countries: The case of Ghana. J. Clean. Prod. 2018, 172, 1067-1079. [CrossRef]

32. Kibert, C.J. Green buildings: An overview of progress. Fla. State Univ. J. Land Use Environ. Law 2004, 19, 491-502.

33. Ofori, G. The Construction Industry: Aspects of Its Economics and Management; NUS Press: Singapore, 1990; ISBN 9971-69-148-5.

34. Hillebrandt, P.M. The nature of construction economics. In Economic Theory and the Construction Industry; Palgrave Macmillan: London, UK, 1974; pp. 3-8. [CrossRef]

35. Rakhra, A.S.; Wilson, A.J. Building economics and the economics of building. Build. Econ. 1982, 21, 51-53.

36. Jing, Y.-Y.; Bai, H.; Wang, J.-J.; Liu, L. Life cycle assessment of a solar combined cooling heating and power system in different operation strategies. Appl. Energy 2012, 92, 843-853. [CrossRef]

37. Iribarren, D.; Vázquez-Rowe, I.; Rugani, B.; Benetto, E. On the feasibility of using emergy analysis as a source of benchmarking criteria through data envelopment analysis: A case study for wind energy. Energy 2014, 67, 527-537. [CrossRef]

38. Kosareo, L.; Ries, R. Comparative environmental life cycle assessment of green roofs. Build. Environ. 2007, 42, 2606-2613. [CrossRef]

39. Zabalza Bribián, I.; Valero Capilla, A.; Aranda Usón, A. Life cycle assessment of building materials: Comparative analysis of energy and environmental impacts and evaluation of the eco-efficiency improvement potential. Build. Environ. 2011, 46, 1133-1140. [CrossRef]

40. Narayan, P.K.; Narayan, S.; Popp, S. A note on the long-run elasticities from the energy consumption-GDP relationship. Appl. Energy 2010, 87, 1054-1057. [CrossRef]

41. Narayan, S.; Doytch, N. An investigation of renewable and non-renewable energy consumption and economic growth nexus using industrial and residential energy consumption. Energy Econ. 2017, 68, 160-176. [CrossRef]

42. Chen, C.; Ibekwe-SanJuan, F.; Hou, J. The structure and dynamics of cocitation clusters: A multiple-perspective cocitation analysis. J. Am. Soc. Inf. Sci. Technol. 2010, 61, 1386-1409. [CrossRef]

43. Börner, K.J.M.P. Atlas of Science: Visualizing What We Know; Cambridge: Boston, MA, USA, 2010. [CrossRef]

44. Li, X.; Wu, P.; Shen, G.Q.; Wang, X.; Teng, Y. Mapping the knowledge domains of Building Information Modeling (BIM): A bibliometric approach. Autom. Constr. 2017, 84, 195-206. [CrossRef]

45. Chaomei, C. Science mapping: A systematic review of the literature. J. Data Inf. Sci. 2017, 2, 1-40. [CrossRef]

46. Cobo, M.J.; López-Herrera, A.G.; Herrera-Viedma, E.; Herrera, F. Science mapping software tools: Review, analysis, and cooperative study among tools. J. Am. Soc. Inf. Sci. Technol. Banner 2011, 62, 1382-1402. [CrossRef] 
47. Sedighi, M.; Jalalimanesh, A. Mapping research trends in the field of knowledge management. Malays. J. Libr. Inf. Sci. 2017, 19, 71-85.

48. Aghaei Chadegani, A.; Salehi, H.; Yunus, M.; Farhadi, H.; Fooladi, M.; Farhadi, M.; Ale Ebrahim, N.J. A comparison between two main academic literature collections: Web of Science and Scopus databases. Asian Soc. Sci. 2013, 9, 18-26. [CrossRef]

49. Olubunmi, O.A.; Xia, P.B.; Skitmore, M. Green building incentives: A review. Renew. Sustain. Energy Rev. 2016, 59, 1611-1621. [CrossRef]

50. Chegut, A.; Eichholtz, P.; Kok, N. Supply, demand and the value of green buildings. Urban Stud. 2013, 51, 22-43. [CrossRef]

51. Fan, K.; Chan, E.H.; Qian, Q.K. Transaction costs (TCs) in green building (GB) incentive schemes: Gross Floor Area (GFA) Concession Scheme in Hong Kong. Energy Policy 2018, 119, 563-573. [CrossRef]

52. Kahn, M.E.; Kok, N. The capitalization of green labels in the California housing market. Reg. Sci. Urban Econ. 2014, 47, 25-34. [CrossRef]

53. Lützkendorf, T.; Lorenz, D. Sustainable property investment: Valuing sustainable buildings through property performance assessment. Build. Res. Inf. 2005, 33, 212-234. [CrossRef]

54. Von Paumgartten, P. The business case for high performance green buildings: Sustainability and its financial impact. J. Facil. Manag. 2003, 2, 26-34. [CrossRef]

55. Darko, A.; Chan, A.P.C. Critical analysis of green building research trend in construction journals. Habitat Int. 2016, 57, 53-63. [CrossRef]

56. Hosseini, M.R.; Martek, I.; Zavadskas, E.K.; Aibinu, A.A.; Arashpour, M.; Chileshe, N. Critical evaluation of off-site construction research: A Scientometric analysis. Autom. Constr. 2018, 87, 235-247. [CrossRef]

57. Santos, R.; Costa, A.A.; Grilo, A. Bibliometric analysis and review of Building Information Modelling literature published between 2005 and 2015. Autom. Constr. 2017, 80, 118-136. [CrossRef]

58. Robichaud, L.B.; Anantatmula, V.S. Greening project management practices for sustainable construction. J. Manag. Eng. 2010, 27, 48-57. [CrossRef]

59. Ding, G.K.C. Sustainable construction-The role of environmental assessment tools. J. Environ. Manag. 2008, 86, 451-464. [CrossRef]

60. Häkkinen, T.; Belloni, K. Barriers and drivers for sustainable building. Build. Res. Inf. 2011, 39, $239-255$. [CrossRef]

61. Hwang, B.-G.; Tan, J.S. Green building project management: Obstacles and solutions for sustainable development. Sustain. Dev. 2012, 20, 335-349. [CrossRef]

62. Zhang, X.; Platten, A.; Shen, L. Green property development practice in China: Costs and barriers. Build. Environ. 2011, 46, 2153-2160. [CrossRef]

63. Eichholtz, P.; Kok, N.; Quigley, J.M. Doing well by doing good Green office buildings. Am. Econ. Rev. 2010, 100, 2492-2509. [CrossRef]

64. Fuerst, F.; McAllister, P. Green noise or green value? Measuring the effects of environmental certification on office values. Real Estate Econ. 2011, 39, 45-69. [CrossRef]

65. Fang, Y.; Yin, J.; Wu, B. Climate change and tourism: A scientometric analysis using CiteSpace. J. Sustain. Tour. 2018, 26, 108-126. [CrossRef]

66. Hu, J.; Zhang, Y. Research patterns and trends of Recommendation System in China using co-word analysis. Inf. Process. Manag. 2015, 51, 329-339. [CrossRef]

67. Ortiz, O.; Castells, F.; Sonnemann, G. Sustainability in the construction industry: A review of recent developments based on LCA. Constr. Build. Mater. 2009, 23, 28-39. [CrossRef]

68. Kneifel, J. Life-cycle carbon and cost analysis of energy efficiency measures in new commercial buildings. Energy Build. 2010, 42, 333-340. [CrossRef]

69. Lee, C.; Hong, T.; Lee, G.; Jeong, J. Life-cycle cost analysis on glass type of high-rise buildings for increasing energy efficiency and reducing CO2 emissions in Korea. J. Constr. Eng. Manag. 2011, 138, 897-904. [CrossRef]

70. MacNaughton, P.; Cao, X.; Buonocore, J.; Cedeno-Laurent, J.; Spengler, J.; Bernstein, A.; Allen, J. Energy savings, emission reductions, and health co-benefits of the green building movement. J. Expo. Sci. Environ. Epidemiol. 2018, 28, 307-318. [CrossRef]

71. Manganelli, B.; Morano, P.; Tajani, F.; Salvo, F. Affordability assessment of energy-efficient building construction in Italy. Sustainability 2019, 11, 249. [CrossRef] 
72. Wang, W.; Zmeureanu, R.; Rivard, H. Applying multi-objective genetic algorithms in green building design optimization. Build. Environ. 2005, 40, 1512-1525. [CrossRef]

73. Lam, P.T.I.; Chan, E.H.W.; Poon, C.S.; Chau, C.K.; Chun, K.P. Factors affecting the implementation of green specifications in construction. J. Environ. Manag. 2010, 91, 654-661. [CrossRef]

74. Cajias, M.; Piazolo, D. Green performs better: Energy efficiency and financial return on buildings. J. Corp. Real Estate 2013, 15, 53-72. [CrossRef]

75. Ma, Y.; Kelman, A.; Daly, A.; Borrelli, F. Predictive control for energy efficient buildings with thermal storage: Modeling, stimulation, and experiments. IEEE Control Syst. Mag. 2012, 32, 44-64. [CrossRef]

76. Komnitsas, K.A. Potential of geopolymer technology towards green buildings and sustainable cities. Procedia Eng. 2011, 21, 1023-1032. [CrossRef]

77. Jaillon, L.; Poon, C.S.; Chiang, Y.H. Quantifying the waste reduction potential of using prefabrication in building construction in Hong Kong. Waste Manag. 2009, 29, 309-320. [CrossRef]

78. Kamel, E.; Memari, A.M. Review of BIM's application in energy simulation: Tools, issues, and solutions. Autom. Constr. 2019, 97, 164-180. [CrossRef]

79. Sailor, D.J. A green roof model for building energy simulation programs. Energy Build. 2008, 40, 1466-1478. [CrossRef]

80. Castro-Lacouture, D.; Sefair, J.A.; Flórez, L.; Medaglia, A.L. Optimization model for the selection of materials using a LEED-based green building rating system in Colombia. Build. Environ. 2009, 44, 1162-1170. [CrossRef]

81. Wang, W.; Rivard, H.; Zmeureanu, R. Floor shape optimization for green building design. Adv. Eng. Inf. 2006, 20, 363-378. [CrossRef]

82. Dagdougui, H.; Minciardi, R.; Ouammi, A.; Robba, M.; Sacile, R. Modeling and optimization of a hybrid system for the energy supply of a "Green" building. Energy Convers. Manag. 2012, 64, 351-363. [CrossRef]

83. Zhai, X.Q.; Wang, R.Z.; Dai, Y.J.; Wu, J.Y.; Xu, Y.X.; Ma, Q. Solar integrated energy system for a green building. Energy Build. 2007, 39, 985-993. [CrossRef]

84. Dunning, T. Accurate methods for the statistics of surprise and coincidence. Comput. Linguist. 1993, 19, 61-74.

85. Salton, G.; Wong, A.; Yang, C.S. A vector space model for automatic indexing. Commun. ACM 1975, 18, 613-620. [CrossRef]

86. He, Q.; Wang, G.; Luo, L.; Shi, Q.; Xie, J.; Meng, X. Mapping the managerial areas of Building Information Modeling (BIM) using scientometric analysis. Int. J. Proj. Manag. 2017, 35, 670-685. [CrossRef]

87. Kaufman, L.; Rousseeuw, P.J. Finding Groups in Data: An Introduction to Cluster; John Wiley \& Sons: Hoboken, NJ, USA, 2009; Volume 344. [CrossRef]

88. Sandström, U.G. Green infrastructure planning in urban Sweden. Plan. Pract. Res. 2002, 17, 373-385. [CrossRef]

89. Abdulmalek, F.A.; Rajgopal, J. Analyzing the benefits of lean manufacturing and value stream mapping via simulation: A process sector case study. Int. J. Prod. Econ. 2007, 107, 223-236. [CrossRef]

90. Chen, C. CiteSpace II: Detecting and visualizing emerging trends and transient patterns in scientific literature. J. Am. Soc. Inf. Sci. Technol. 2006, 57, 359-377. [CrossRef]

91. Jin, Y.; Ji, S.; Li, X.; Yu, J. A scientometric review of hotspots and emerging trends in additive manufacturing. J. Manuf. Technol. Manag. 2017, 28, 18-38. [CrossRef]

92. Chen, C.; Hu, Z.; Liu, S.; Tseng, H. Emerging trends in regenerative medicine: A scientometric analysis in CiteSpace. Exp. Opin. Biol. Ther. 2012, 12, 593-608. [CrossRef]

93. Miller, N.; Spivey, J.; Florance, A. Does green pay off? J. Real Estate Portf. Manag. 2008, 14, 385-399.

94. Ali, H.H.; Al Nsairat, S.F. Developing a green building assessment tool for developing countries-Case of Jordan. Build. Environ. 2009, 44, 1053-1064. [CrossRef]

95. Haapio, A.; Viitaniemi, P. A critical review of building environmental assessment tools. Environ. Impact Assess. Rev. 2008, 28, 469-482. [CrossRef]

96. Chan, E.H.W.; Qian, Q.K.; Lam, P.T.I. The market for green building in developed Asian cities-the perspectives of building designers. Energy Policy 2009, 37, 3061-3070. [CrossRef]

97. Hwang, B.-G.; Ng, W.J. Project management knowledge and skills for green construction: Overcoming challenges. Int. J. Proj. Manag. 2013, 31, 272-284. [CrossRef] 
98. Lutzenhiser, L. 19 Greening the Economy from the Bottom up? Lessons in Consumption from the Energy Case. Read. Econ. Soc. 2002, 19, 345-356.

99. Zuo, J.; Pullen, S.; Rameezdeen, R.; Bennetts, H.; Wang, Y.; Mao, G.; Duan, H. Green building evaluation from a life-cycle perspective in Australia: A critical review. Renew. Sustain. Energy Rev. 2017, 70, 358-368. [CrossRef]

100. Kibert, C.J. Establishing principles and a model for sustainable construction. In Proceedings of the First International Conference on Sustainable Construction, Tampa, FL, USA, 6-9 November 1994.

101. Gilg, A.; Barr, S.; Ford, N.J.F. Green consumption or sustainable lifestyles? Identif. Sustain. Consum. 2005, 37, 481-504.

102. Zuo, J.; Jin, X.-H.; Flynn, L. Social sustainability in construction-an explorative study. Int. J. Constr. Manag. 2012, 12, 51-63. [CrossRef]

103. Singh, B.; Garg, S.K.; Sharma, S.K. Value stream mapping: Literature review and implications for Indian industry. Int. J. Adv. Manuf. Technol. 2011, 53, 799-809. [CrossRef]

104. Gou, Z.; Xie, X. Evolving green building: Triple bottom line or regenerative design? J. Clean. Produc. 2017, 153, 600-607. [CrossRef]

105. Petrovic-Lazarevic, S. Economics. The development of corporate social responsibility in the Australian construction industry. Constr. Manag. Econ. 2008, 26, 93-101. [CrossRef]

106. Xiao, X.; Wang, F.; Li, H.; Skitmore, M. Modelling the stochastic dependence underlying construction cost and duration. J. Civ. Eng. Manag. 2018, 24, 444-456. [CrossRef]

107. Matisoff, D.C.; Noonan, D.S.; Flowers, M.E. Policy monitor-Green buildings: Economics and policies. Rev. Environ. Econ. Policy 2016, 10, 329-346. [CrossRef]

(C) 2019 by the authors. Licensee MDPI, Basel, Switzerland. This article is an open access article distributed under the terms and conditions of the Creative Commons Attribution (CC BY) license (http://creativecommons.org/licenses/by/4.0/). 